\title{
DESCRIPTION AND KEY TO THE ZOEAL STAGES OF THE CAMPYLONOTIDAE (DECAPODA, CARIDEA) FROM THE MAGELLAN REGION
}

\author{
Sven Thatje, Rosa Bacardit, M. Carolina Romero, Federico Tapella, \\ and Gustavo A. Lovrich
}

(ST, correspondence) Alfred Wegener Institute for Polar and Marine Research, P.O. Box 120161 , D-27515 Bremerhaven, Germany (e-mail: sthatje@awi-bremerhaven.de); (RB) Juana Azurduy I611, 1424 Buenos Aires, Argentina; (MCR, FT, GAL) Centro Austral de Investigaciones Científicas, CC 92, 9410 Ushuaia, Tierra del Fuego, Argentina

\section{A B S T R A C T}

The present work provides a first description of the zoeal stages of the Caridean prawns Campylonotus vagans, $C$. semistriatus and $C$. capensis Bate, 1888. Zoeal stages one and two were obtained from plankton catches during several expeditions in the Magellan region and the southwestern Atlantic Ocean, and first zoeae of $C$. vagans were confirmed with larvae hatched in a laboratory culture. Based on the results obtained, we conclude the morphological differences of the presence/absence of carapace spines, the shape of the somites, the telson and its number of posterolateral spines to serve as diagnostic features for the determination of campylonotid larvae. Morphological comparisons with larvae of the Pandalidae, Palaemonidae, and Oplophoridae suggest the Campylonotidae to be phylogenetically related to the Oplophoridae. Additionally, a key for identifying the zoeal stages of the Campylonotidae from the southernmost region of America is given in order to facilitate future ecological and life history studies.

\section{RES U M EN}

El presente trabajo provee una primera descripción para los estadíos larvales de los camarones Caridea Campylonotus vagans, C. semistriatus y C. capensis Bate 1888. Los estadíos larvales de las zoeas uno y dos fueron obtenidos con una red de plancton durante varias expediciones en la Región Magallánica y en el Océano Atlántico sudoccidental y el estadío uno de $C$. vagans fue también confirmado con larvas eclosionadas de huevos en el laboratorio. Basándonos en los resultados obtenidos, concluimos que las diferencias morfológicas de presencia/ ausencia de espinas en el cefalotórax, el aspecto de los somites, del telson y su número de espinas postlaterales sirven como caracteres diagnóstico para la determinación de las larvas de Campylonotidae. Las comparaciones morfológicas de las larvas de Campylonotus con las de las familias Pandalidae, Palaemonidae, y Oplophoridae refiejan mayor afinidad filogenética con las de esta última familia. Se presenta una clave para identificar los estadíos larvales de los Campylonotidae en aguas de América del Sur y para facilitar estudios ecológicos y de ciclos de vida.

The knowledge of benthic invertebrates and their larvae from the subantarctic Magellan region is currently very limited (e.g., Thatje and Mutschke, 1999; Lovrich, 1999). There is still a lack of ecological studies on, and especially descriptions and keys for the identification of, meroplanktonic larvae. Only decapod larvae have been investigated more closely; thus, larval descriptions are available for the most common species occurring in the Magellan region (Albornoz and Wehrtmann, 1997; Wehrtmann and Báez, 1997; Lovrich, 1999). Even now, only the first zoeal stage of Campylonotus rathbunae Schmitt, ob- tained from laboratory culturing, has been described by Pike and Williamson (1966). Although this species is not present in the southwestern Atlantic and the Magellan region, very similar larvae were found in plankton samples obtained during various expeditions from 1978 to 1998 which were identified as belonging to Campylonotus.

The Caridean prawn Campylonotus vagans occurs in wide parts of the Chilean coast south to the Magellan region, as well as in the southwestern Atlantic Ocean of Argentina. Campylonotus semistriatus is restricted to the channels and fjords of the Magellan region 
and the southwestern Atlantic, and a third species, $C$. capensis, is known to be distributed only in the southwestern Atlantic (Fig. 1; Torti and Boschi, 1973; Retamal, 1981; Spivak, 1997; Gorny, 1999). The present work provides new descriptions of the campylonotid larval stages in order to facilitate future studies on larval ecology, life history, and stock recruitment.

Additionally, we present a key to the larvae of all three species from the Magellan region, which allows the determination of planktonic campylonotid larvae from the Chilean and Argentine coasts. Furthermore we compare these descriptions with those of Pike and Williamson (1966) for C. rathbunae.

\section{Materials AND METHODS}

The material studied was collected in 1978 by the German vessel "Walther Herwig" during cruises III/1 (5th leg) and IIV/2 (6th leg) carried out on the Argentine shelf and continental slope in the southwestern Atlantic Ocean (Fig. 1). Samples were collected vertically from the seafloor to the surface or $100 \mathrm{~m}$ to the surface by means of a Bongo net of $330 \mu \mathrm{m}$ mesh size and were preserved in $3 \%$ Formalin solution buffered with hexamethylenetetramine. Complete descriptions of the cruises and additional information on oceanographic measurements can be obtained from Ciechomski et al. (1979) and Cousseau et al. (1979).

The larval material caught during the "Walther Herwig" cruises has been compared to the material collected by a plankton net of $200 \mu \mathrm{m}$ mesh size by monthly sampling from onboard a Zodiac in the Beagle Channel (Tierra del Fuego) from 1987 to 1989 (see Lovrich, 1999).

The first zoeal stage of $C$. vagans was confirmed with larvae hatched in laboratory culturing of ovigerous females with an advanced embryonic egg stage, which were collected with an epibenthic trawl from onboard an infiatable dinghy in the Beagle Channel (Magellan region, Fig. 1) in September 1999.

Carapace (CL) and total (TL) lengths of the larvae were measured from the base of the rostrum between the eyes to the posterior dorsal margin of the carapace and to the posterior margin of the telson, respectively. The terminology used for the differentiation of the larval phases, the larval morphology and the characteristics between species and larval stages, corresponds to that suggested by Williamson (1960. 1968, 1982), Gurney (1942), Boschi (1981), Haynes (1978. 1981, 1985), and Clark et al. (1998).

\section{RESULTS}

Family Campylonotidae Campylonotus vagans Bate, 1888

Zoea I.-(Fig. 2): TL $=5.8 \pm 0.06 \mathrm{~mm} ; \mathrm{CL}$ $=1.9 \pm 0.01 \mathrm{~mm} ; n=18$.

Cephalothorax (Fig. 2A). Rostrum straight, without dorsal spines at base. Eyes sessile.

Antennule (Fig. 2E). Uniramous. Peduncle unsegmented, with I long plumose seta at inner distal end. Endopod absent. Exopod unsegmented, with 4 aesthetascs and 1 subterminal plumose seta.

Antenna (Fig. 2D). Biramous. Protopod unsegmented, with 1 well-developed spine at inner distal end and 1 shorter terminal central spine. Endopod unsegmented, with 1 long apical plumose seta. Exopod (scaphocerite) with 10 terminal plumose setae and 1 long plumose medial seta.

Mandible (Fig. 2F). Well-developed molar and incisor processes, with lacinia mobilis. Palp absent.

Maxillule (Fig. 2G). Coxal endite with 20 plumodenticulate setae. Basial endite with 13 or 14 plumodenticulate setae. Endopod 2-segmented, proximal segment with 2 plumodenticulate setae, distal segment with 3 terminal plumodenticulate setae. Two simple setae at base of endopod. Exopod absent.

Maxilla (Fig. 2H). Coxal endites proximally and distally with 26 and 4 setae, respectively. Basal endites with 12 setae at each side. Endopod 2-segmented, proximal segment with 3, 2 setae and distal segment with 5 setae arranged 1, 2, 2. Exopod (scaphognathite) with 30-32 marginal plumose setae.

Maxilliped 1 (Fig. 2I). Coxa and basis with 8 and 29-31 setae, respectively. Endopod 4-segmented with 9 plumodenticulate setae arranged $2+0,2+0,2+0,3$ terminal. Exopod unsegmented, with 9 long terminal plumose natatory setae. Epipod present.

Maxilliped 2 (Fig. 2J). Coxa with 2 medial plumodenticulate setae. Basis with 9 medial plumodenticulate setae arranged 3, 3, 3 . Endopod 5-segmented, with 14 plumodenticulate setae arranged $2+1,2+1,0+1,2+1,4$ terminal. Exopod unsegmented, with 14 long terminal plumose natatory setae. Epipod present.

Maxilliped 3 (Fig. 2K). Coxa unarmed. Basis with 4 medial plumodenticulate setae arranged 2, 2. Endopod 5-segmented, with 13 plumodenticulate setae arranged $3+0,1+1$, $1+0,2+1,4$ terminal. Exopod unsegmented, with 17 long terminal plumose natatory setae. Epipod present

Pereiopods (Fig. 2L-P). Pereiopod 1, endopod 5-segmented; segments 1-3 without setation; propodus with 2 plumose distal setae; dactylus with 2 apical setae; exopod unsegmented, without setation. Pereiopod 2, endopod 5-segmented, segments $1-3$ without setation; propodus with $1+1$ plumose setae, dactylus with 1 terminal plumose seta; exopod unsegmented, without setation. Pereio- 


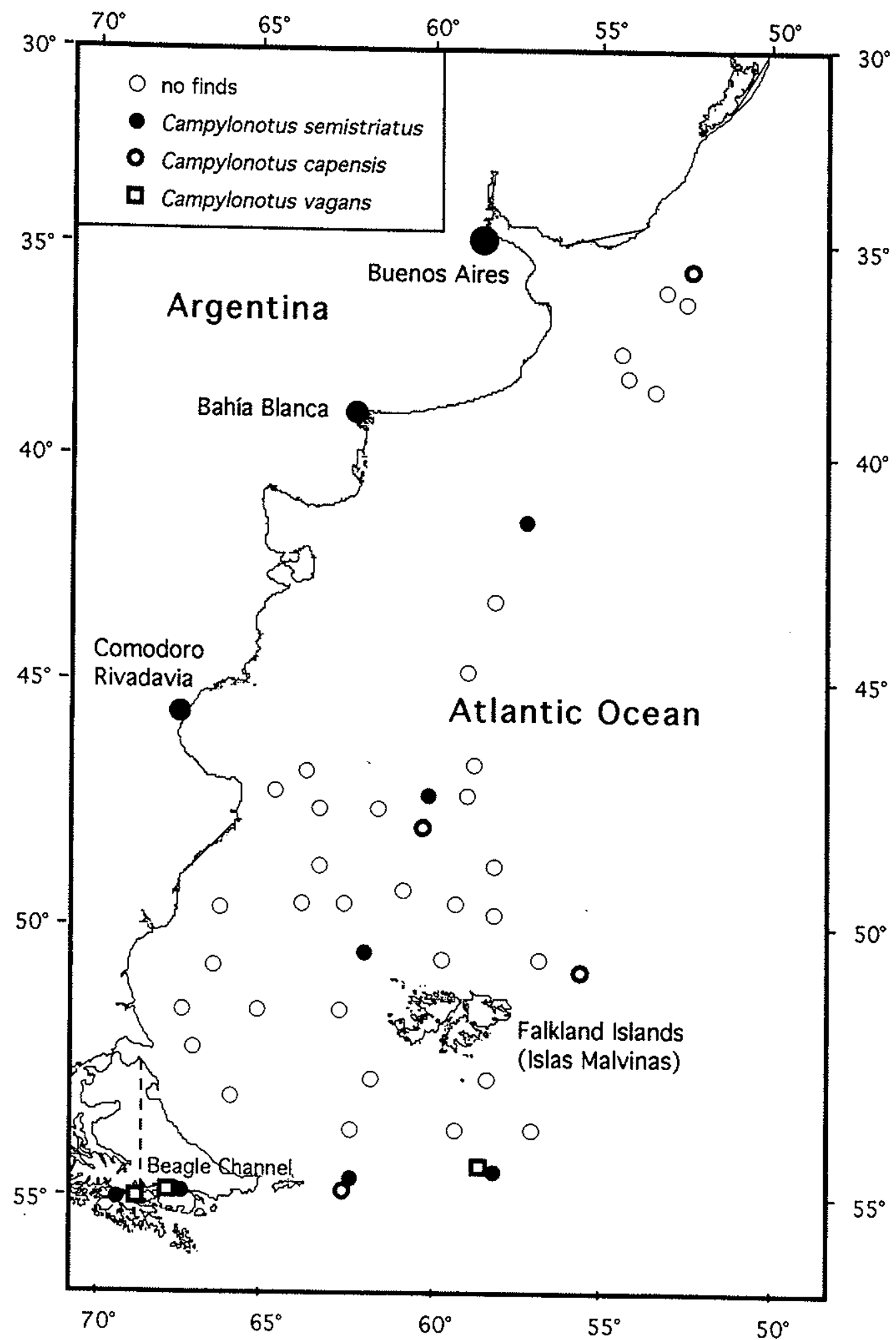

Fig. 1. Sampling locations of campylonotid larvae in the Magellan region and the southwestern Atlantic Ocean. 


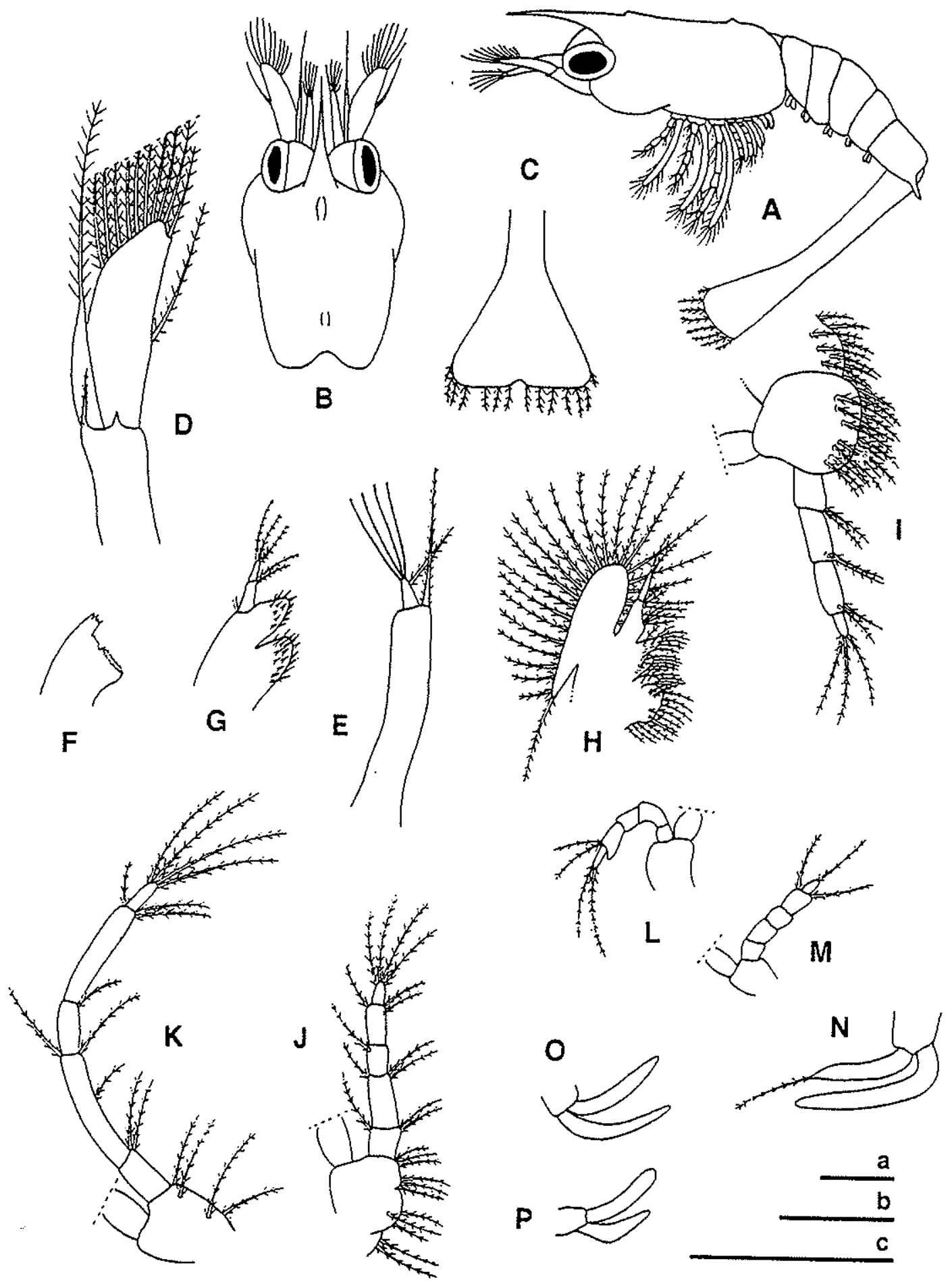

Fig. 2. First zoeal stage of Campylonons vagans; A, whole animal, lateral view; B, carapace with cephalic appendages. dorsal view; $C$. telson, ventral view: $D$, antenna: $E$, antennule: $F$, mandible: $G$, maxillule; $H$, maxilla; $I$, maxilliped 1 . lateral view: J, maxilliped 2 . lateral view; $K$, maxilliped 3 . lateral view; $L$, pereiopod I. lateral view; M. pereiopod 2. lateral view: N. pereiopod 3. lateral view; O. pereiopod 4, lateral view; $P$, pereiopod S, lateral view. Scale bars: $a=1 \mathrm{~mm}$ (Figs. A-C); $b=0.5 \mathrm{~mm}$ (Figs. D-K): $c=1 \mathrm{~mm}$ (Figs. L-P). 
pod 3, endopod unsegmented, with 1 terminal plumodenticulate seta; exopod slightly longer than endopod, unsegmented, unarmed. Pereiopods 4 and 5, rudimentary, biramous.

Abdomen (Fig. 2A). Five abdominal somites, without expansions or ornamentation. Somite 5 with 1 long spine on posterolateral margin. Pleopods absent.

Telson (Fig. 2C). Triangular, with strong medial cleft and 7 pairs of processes on posterior margin.

Zoea 1I. -(Fig. 3): $\mathrm{TL}=6.9 \pm 0.05 \mathrm{~mm}$; LC $=2.0 \pm 0.03 \mathrm{~mm} ; n=9$.

Cephalothorax (Fig. 3A). Rostrum straight, smooth, with 2 dorsal spines at base. Pterygostomic and supraorbital spines present, the last well developed. One dorsal posterior protuberance. Eyes now stalked.

Antennule (Fig. 3C). Peduncule 3-segmented, first segment with one conspicuous medial spine, $2+6$ terminal plumodenticulate setae, stylocerite rudimentary, reduced to small bud near base; second and third segments with $2+4$ and $1+5+1+5$ plumodenticulate setae, respectively. Endopod now present, with small, apical simple seta. Exopod unsegmented, with 13 aesthetascs, arranged 3 , $3,3,4$.

Antenna (Fig. 3D). Endopod 3-segmented, basial segment unarmed, second segment with 1 plumodenticulate seta, distal segment with 1 apical simple seta. Exopod (scaphocerite) with 27-29 plumodenticulate setae. No other changes.

Mandible (Fig. 3B). Unchanged.

Maxillule (Fig. 3E). Basial endite with 25 plumodenticulate setae. No other changes.

Maxilla (Fig. 3I). Basial endite with $13+14$ plumodenticulate setae. Endopod unsegmented, with 10 plumodenticulate setae, arranged 3, 2, 1, 2, 2. Scaphognathite now with 30 or 31 plumose marginal setae. No other changes.

Maxilliped 1 (Fig. 3F). Basis with 34 plumodenticulate setae. Exopod with 12 long terminal plumose setae. No other changes.

Maxilliped 2 (Fig. $3 G$ ). Exopod now with 18 long terminal plumose natatory setae. No other changes.

Maxilliped 3 (Fig. 3J). Basis with 5 medial plumodenticulate setae. Endopod 5-segmented, with 17 plumodenticulate setae, arranged $3+0,2+2,0+2,4+2,2$ terminal. No other changes.

Pereiopods (Fig. 3K-O). Pereiopod 1, ba- sis with 4 plumodenticulate setae, endopod 5-segmented, ischium, merus, carpus, propodus, and dactylus with $2,2,3,7,3$ plumodenticulate setae, respectively; propodus and dactylus as well-developed chela; exopod with 16 plumose setae. Pereiopod 2, basis with 3 plumodenticulate setae, endopod 5 -segmented, ischium, merus, carpus, propodus, and dactylus with $2,2,2,7,3$ plumodenticulate setae, respectively (dactylus with 1 strong apical spine), propodus and dactylus as well-developed chela; exopod with 16 plumose setae. Pereiopod 3, basis with 4 plumodenticulate setae, endopod 5-segmented, with 2, 3, 2, 4, 3 plumodenticulate setae, respectively; exopod with 16 plumose setae. Pereiopod 4 , basis with 2 plumodenticulate setae, endopod 5-segmented, with 2 , $3,3,5,2$ plumodenticulate setae (dactylus with 1 apical spine), exopod with 12 plumose setae. Pereiopod 5, endopod 5-segmented, with $0,3,2,5,2$ plumodenticulate setae, respectively (dactylus with 1 apical spine), exopod reduced and unarmed.

Abdomen (Fig. 3A). Spine on posterolateral margin of somite 5 relatively shorter. Pleopodal buds present. No other changes.

Telson (Fig. 3H). One new pair of processes (now 8 pairs) at inner posterior margin. Uropods biramous, unarmed.

\section{Campylonotus semistriatus Bate, 1888}

Zoea I.-(Fig. 4): $\mathrm{TL}=8.4 \pm 0.08 \mathrm{~mm}$; CL $=2.2 \pm 0.02 \mathrm{~mm} ; n=13$.

Cephalothorax (Fig. 4A). Rostrum straight, with 15 small spines; anteroventral margin with pterygostomic spine and 14 denticles. Two dorsal protuberances. Eyes sessile.

Antennule (Fig. 4D). Uniramous. Peduncle unsegmented, with inner distal plumose seta. Endopod absent. Exopod unsegmented, with 4 aesthetascs and one subterminal plumose seta.

Antenna (Fig. 4E). Biramous. Protopod unsegmented, no terminal spine, 1 medial and 1 terminal spine on outer margin. Endopod unsegmented, with 1 long apical plumose seta and well-developed inner spine; spinulose ventral spine at base of endopod. Exopod (scaphocerite) with 11 terminal plumose setae and 1 long plumose medial seta.

Mandible (Fig. 4F). Well-developed molar and incisor processes; with lacinia mobilis. Palp absent.

Maxillule (Fig. 4G). Coxal endite with 20-22 plumodenticulate setae. Basial endite 

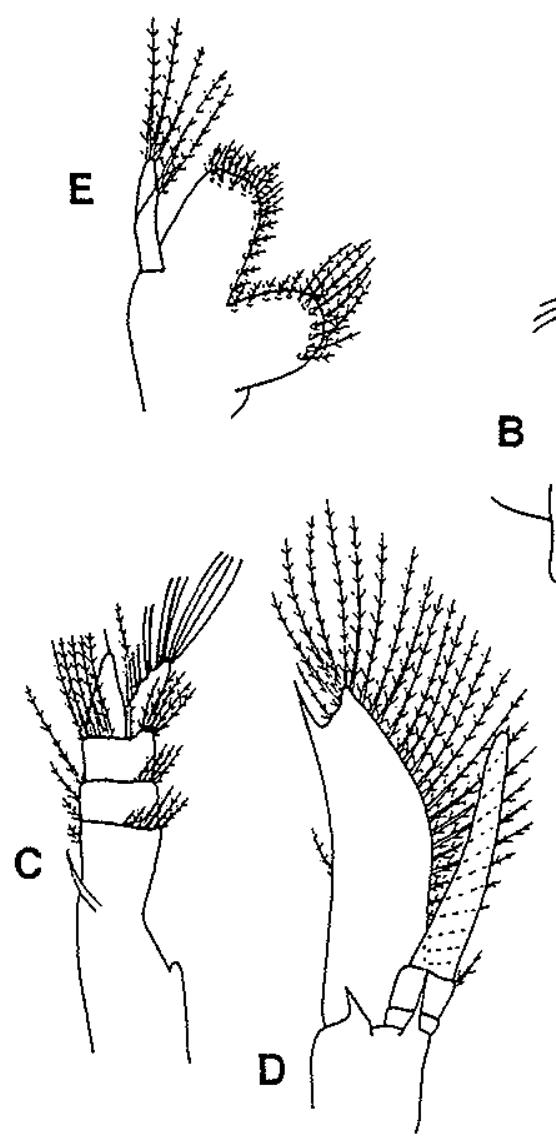

B
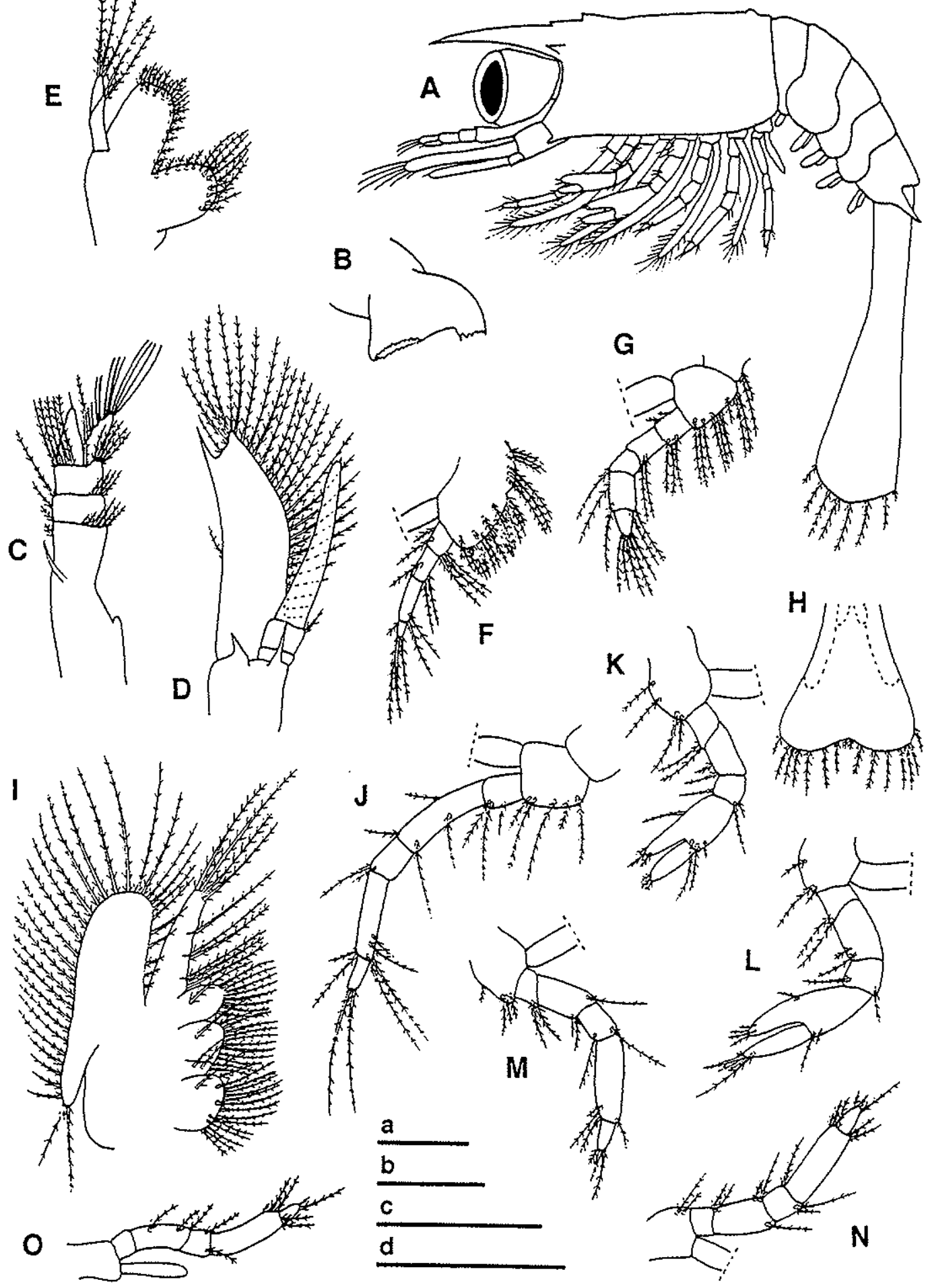

Fig. 3. Second zoeal stage of Campylonotus vagans; A. whole animal, lateral view: B. mandible: $C$, antennule; $D$ antenna: $E$, maxillule, aboral view; $\dot{F}$, maxilliped 1, lateral view; $G$, maxilliped 2 . lateral view; $H$, teison, ventral view: I. maxilla: J, maxilliped 3, lateral view: K. pereiopod I, lateral view; L. pereiopod 2. law; H. teison, ventral pod 3. lateral view; $N$, pereiopod 4. lateral view; 0 . pereiopod 5 lateral view. Scelepod 2. lateral view; $M$, perejo$\mathrm{mm}$ (Fig. A): $\mathrm{c}=0.5 \mathrm{~mm}$ (Figs. B, E, I ) $\mathrm{d}=1 \mathrm{~mm}$ (Figs. C, D, F, G. J-O). 


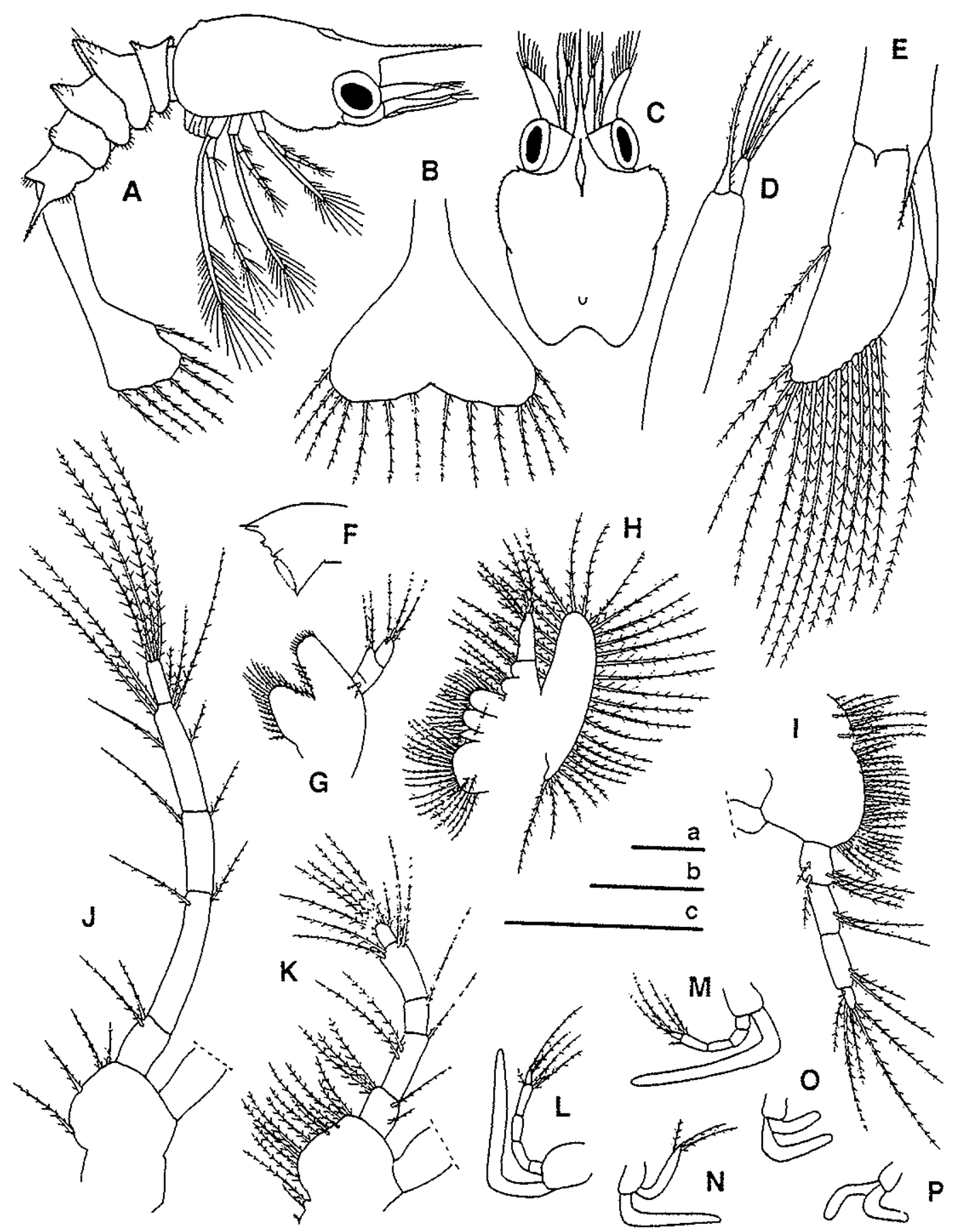

Fig. 4. First zoeal stage of Campylonotus semistriatus: A. whole animal. lateral view: B. teison, ventral view: $C$, carapace, dorsal view; $D$, antennule: E. antenna: F. mandible: G. maxillule. aboral view: $H$. maxilla, aboral view; I, maxilliped I. lateral view; J, maxilliped 3. lateral view: K. maxilliped 2. lateral view: L. pereiopod I, lateral view: M. pereiopod 2. lateral view: N. pereiopod 3. lateral view: O. pereiopod 4, lateral view: P. pereiopod 5. lateral view. Scale bars: $a=1 \mathrm{~mm}$ (Figs. A-C): $\mathrm{b}=0.5 \mathrm{~mm}$ (Figs. D-K): $\mathrm{c}=1 \mathrm{~mm}$ (Figs. L-P). 
with 13 or 14 spines and 4 setae. Endopod 2 -segmented, with $2+3$ setae, respectively. Two short, simple setae at base of endopod. Exopod absent.

Maxilla (Fig. $4 \mathrm{H}$ ). Proximal endite of coxa with about 26 setae, distal endite small, bearing 4 setae. Basal endites with 12 setae each. Palp with indications of 5 segments, partial division between first and second, complete division between second and third, segments with $3,2,1,2,2$ setae from proximal to distal, respectively. Exopod (scaphognathite) with 30-32 plumose marginal setae and 1 terminal flagellum with setules.

Maxilliped 1 (Fig. 4I). Coxa and basis with 11 and 29-31 medial plumodenticulate setae respectively. Endopod 4-segmented, with 14 plumodenticulate setae, arranged $3+2,2+0$, $2+0,4+1$ ( 1 subterminal, 4 terminal) setae, respectively. Exopod unsegmented, with 14 long plumose natatory setae. Epipod present.

Maxilliped 2 (Fig. 4K). Coxa with 2 medial plumodenticulate setae. Basis with 12 medial plumodenticulate setae, arranged 4,4 , 4. Endopod 5-segmented, with $3+2,2+1,0+1$, $2+2,5+1$ (1 subterminal, 5 terminal) setae, respectively. Exopod unsegmented, with 16 long plumose natatory setae. Epipod present.

Maxilliped 3 (Fig. 4J). Coxa unarmed. Basis with 4 medial plumodenticulate setae, arranged 1, 1, 2. Endopod 5-segmented with $2+0,1+1.1+1,3+3,4+1$ (1 subterminal, 4 terminal) setae, respectively. Exopod unsegmented with 26 long terminal plumose natatory setae. Epipod present.

Pereiopods (Fig. 4L, P). Pereiopods 1 and 2 , endopod 5-segmented, with $0,0,0,2+1,2$ setae, respectively; with indications of chelae; exopod slightly longer than endopod. Pereiopod 3 , endopod unsegmented, with 2 terminal and 1 subterminal setae; exopod slightly longer than endopod. Pereiopods 4 and 5 rudimentary, biramous.

Abdomen (Fig. 4A). First somite with expanded anterior and posterior dorsal margins; somites 2-5 with only posterior dorsal margins expanded. Somite 5 with 1 long spine on posterolateral margin. Ventral and posterior dorsal margins of all somites fringed with large denticles: fine large plumose setae on dorsal and ventral surface. Somite 6 continuous with telson. Pleopods absent.

Telson (Fig. 4B). Triangular, with strong medial cleft and 7 pairs of processes on posterior margin.
Zoea II.-(Fig. 5): TL $=12 \pm 0.01 \mathrm{~mm} ; \mathrm{CL}$ $=3.4 \pm 0.03 \mathrm{~mm} ; n=11$.

Cephalothorax (Fig. 5A). Rostrum with 9 dorsal spines; anteroventral margin with pterygostomic spine and about 21 denticles. Supraorbital spine present. Two dorsomedial protuberances and 1 well-developed spine bent forward. Eyes now stalked.

Antennule (Fig. 5B). Peduncle 3-segmented, first segment with 1 conspicuous medial spine, stylocerite forming on proximal external margin of first segment, 19 setae on distal external margin and 2 distal internal setae. Second segment with 8 setae on distal external margin and 3 internal setae. Third segment with large external seta, small medial distal lobe with 4 setae, and 2 internal setae. Exopod with 2, 3, 1, 4 aesthetascs, large distal external seta and small internal one.

Antenna (Fig. 5C). Exopod (scaphocerite) unsegmented, with well-developed external spine, 1 medial seta on outer margin, 36-38 marginal setae on distal margin (including tip). Endopod with 2 subterminal and 1 terminal small setae; ventral spines shorter than in first stage.

Mandible (Fig. 5G). Unchanged.

Maxillule: Coxal endite with 23-25 plumodenticulate setae. Basial endite with 22 spines and 6 setae. Palp 3-segmented, with $2,2,3$ setae, respectively, external setae of first segment reduced.

Maxilla: Proximal endite of coxa with about 28 setae, distal endite small, bearing 4 setae; proximal basal endite with 12 marginal and 1 lateral setae; distal basal endite with 12 marginal setae and large one near base of palp. Palp unchanged. Exopod (scaphognathite) with $42-44$ marginal plumose setae and 2 terminal flagella with long setules.

Maxilliped 1 (Fig. 5E). Coxa and basis with 12 and $40-42$ plumodenticulate setae, respectively. Endopod 4-segmented, with $3+0$, $2+0,2+2,2+1$ ( 2 terminal, I subterminal) setae, respectively. Exopod with 14 long plumose natatory setae. Epipod present.

Maxilliped 2 (Fig. 5F). Coxa and basis with 3 and 13 setae, respectively. Endopod 5-segmented, with $3+2,2+1,0+2,2+2,6+1(6$ terminal. I subterminal) setae, respectively. Exopod with 26 long plumose natatory setae. Epipod present.

Maxilliped 3 (Fig. 5H). Coxa and basis with 0 and 5 plumodenticulate setae, respectively. Endopod 5-segmented, with $2+0,1+1$, 
$1+1,4+3,5+1$ ( 5 terminal, 1 short subterminal) setae, respectively; exopod with 30 long plumose natatory setae. Epipod present.

Pereiopods (Fig. 5I-M). Pereiopods 1 and 2 , basis with 4 setae; endopod 5-segmented, with $2+0,1+1,1+1,2+2,1+2$ ( 2 terminal, 1 subterminal) plumodenticulate setae, respectively; exopod with 28 long plumose natatory setae. Pereiopod 3, basis with 3 setae; no other differences to pereiopods 1 and 2 . Pereiopods 4 and 5 , endopod unsegmented, with 2 terminal and 3 subterminal plumodenticulate setae. Exopod unsegmented, unarmed.

Abdomen (Fig. 5A). Posterior dorsal margins of somites less expanded than in first stage. Somite 6 continuous with telson.

Telson (Fig. 5D). Median indentation less pronounced than in zoea I. One new short pair of processes (now 8 pairs) at inner posterior margin. No indication of uropods.

\section{Campylonotus capensis Bate, 1888}

Zoea I.-(Fig. 6): $\mathrm{TL}=7.4 \pm 0.04 \mathrm{~mm} ; \mathrm{CL}$ $=2.0 \pm 0.01 \mathrm{~mm} ; n=7$.

Cephalothorax (Fig. 6A, B). Rostrum straight, without spines; anteroventral margin with pterygostomic spine and 21-23 denticles; 2 dorsal protuberances. Eyes sessile.

Antennule (Fig. 6G). Peduncle unsegmented, with 1 inner distal plumose seta. Endopod absent. Exopod unsegmented, with 4 aesthetascs and 1 subterminal plumose seta.

Antenna (Fig. 6D). Biramous. Protopod unsegmented, with I well-developed spine at inner distal end and 1 shorter terminal central spine. Endopod unsegmented, with 1 long apical plumose seta. Exopod (scaphocerite) with 10 terminal plumose setae and 1 long plumose medial seta.

Mandible (Fig. 6E). Well-developed molar and incisor processes; with lacinia mobilis. Palp absent.

Maxillule (Fig. 6F). Coxal endite with 24-26 plumodenticulate setae. Basial endite with 8 spines and 6 plumodenticulate setae. Endopod 2-segmented, proximal segment with 2 plumodenticulate setae, distal segment with 3 apical setae. Two simple setae at base of endopod. Exopod absent.

Maxilla (Fig. 6H). Proximal endite of coxa with 26-30 setae, distal endite small, bearing 4 setae; basal endites with 12 and 18 proximal and distal setae, respectively; palp with indications of 5 segments, partial divi- sion between first and second, complete division between second and third, segments with $3,2,1,2$, and 2 setae from proximal to distal, respectively; exopod with 30 or 31 marginal plumodenticulate setae and terminal flagellum with long setules.

Maxilliped 1 (Fig. 6I). Coxa and basis with 8 and 27 medial plumodenticulate setae, respectively. Endopod 4-segmented, with 14 plumodenticulate setae, arranged $3+2,1+1$, $2+1,3+1$ ( 3 terminal, 1 subterminal). Exopod unsegmented, with 14 long terminal plumose natatory setae. Epipod present.

Maxilliped 2 (Fig. 6K). Coxa with 2 plumodenticulate setae. Basis with 9 medial plumodenticulate setae, arranged 3, 3, 3. Endopod 5 -segmented, with 18 plumodenticulate setae, arranged $2+2,2+1,0+1,2+2,5+1$ ( 5 terminal, 1 subterminal). Exopod with 22 long terminal plumose natatory setae. Epipod present.

Maxilliped 3 (Fig. 6J). Coxa and basis with 0 and 4 plumodenticulate setae, respectively, arranged 2, 2. Endopod 5-segmented, with 17 plumodenticulate setae, arranged $2+0,1+1$, $1+1,4+3,3+1$ (3 terminal, 1 subterminal). Exopod unsegmented, with 24 long terminal plumose natatory setae. Epipod present.

Pereiopods (Fig. 6L-P). Pereiopod 1, endopod 5-segmented; segments $1-3$ with $1+0$, $1+0,1+1$ plumodenticulate setae, respectively; propodus with 2 distal setae and 2 plumose setae on developing finger; dactylus with 3 apical setae; exopod without setae. Pereiopod 2, endopod 5-segmented, segments $1-3$ with $0+0,1+0,1+0$ plumodenticulate setae, respectively; propodus with $2+2$ plumose setae, dactylus with 3 terminal plumose setae; exopod without setae. Pereiopod 3, endopod unsegmented, with 2 subterminal and 1 terminal setae; exopod slightly longer than endopod. Pereiopod 4, biramous; endopod with 1 terminal seta. Pereiopod 5, biramous, rudimentary.

Abdomen (Fig. 6B). First somite with anterior and posterior margins smooth, not expanded. Somites 2-5 with posterior dorsal margins expanded; fifth somite with large, ventral, smooth spine on each side. Ventral and posterior dorsal margins of all somites (except dorsal margin of first) fringed with denticles; fine setae on dorsal surface. Somite 6 continuous with telson. No trace of pleopods.

Telson (Fig. 6C). Triangular, with medial cleft and 7 pairs of processes on posterior margin. 


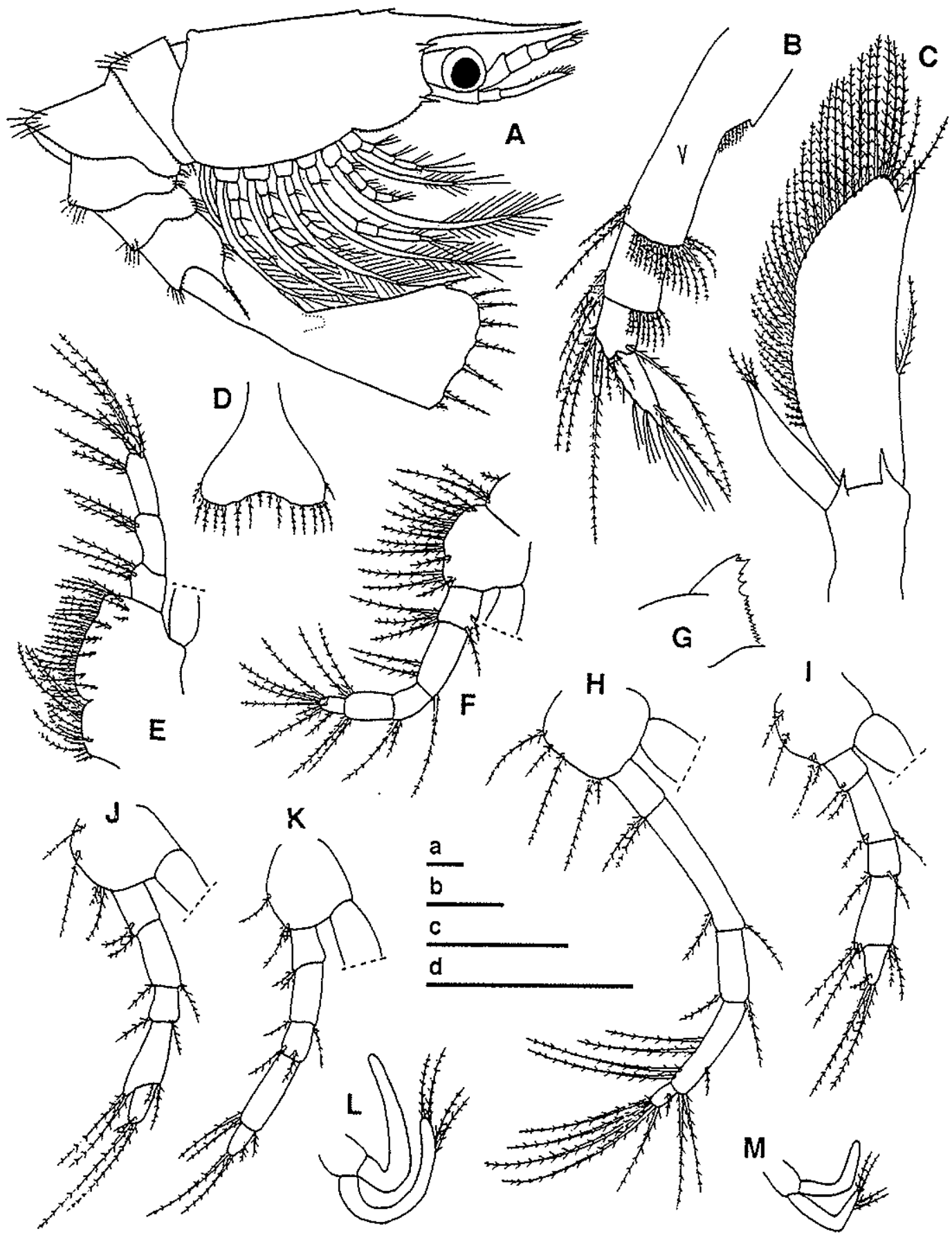

Fig. 5. Second zoeal stage of Campylonotus semistriatus; A, whole animal, lateral view; B, antennule; C, antenna; D. telson, ventral view; E. maxilliped 1, lateral view; F, maxilliped 2, lateral view: G, mandible; H, maxilliped 3 , lateral view: 1. pereiopod I. lateral view; J, pereiopod 2, lateral view; $K$, pereiopod 3, lateral view; L, pereiopod 4, lateral view: $M$. pereiopod 5. lateral view. Scale bars: $a-d=I \mathrm{~mm}$ a (Fig. D). b (Fig. A), c (Figs. L, M), d (Figs. B. C. E-K). 


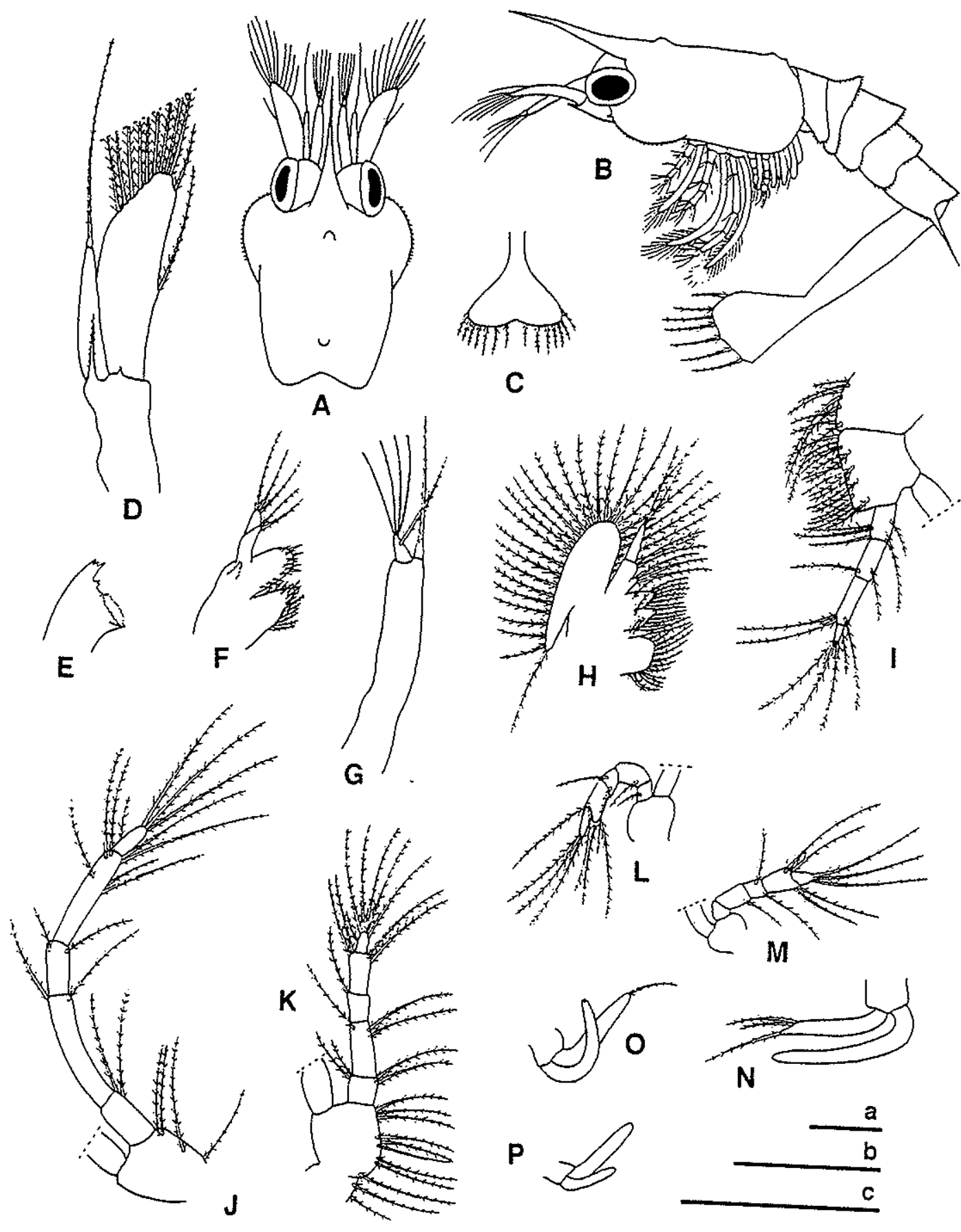

Fig. 6. First zoeal stage of Campylonotus capensis; A, carapace, dorsal view: B, whole animal, lateral view; $C$, telson. ventral view: D. antenna; E. mandible: F. maxillule; G. antennule; $H$, maxilla; $I$. maxilliped 1 ; J, maxilliped 3 : K. maxilliped 2: L. pereiopod 1. latera! view; M. pereiopod 2. lateral view: N. pereiopod 3, lateral view: O, pereiopod 4. lateral view; P. pereiopod 5. lateral view. Scale bars: $a=2 \mathrm{~mm}$ (Fig. D), $b=2 \mathrm{~mm}$ (Figs. A. B): $c=1 \mathrm{~mm}$
(Figs. D-P). 


\section{KEY TO ZOEAL STAGES I AND II OF THE CAMPYLONOTIDAE FROM THE MAgellaN REgion}

1. Eyes sessile. pereiopods less developed, rudimentary: carapace with anterior and posterior dorsal protuberance: telson with $7+7$ distal setae . . . zoea I, 2

- Eyes stalked, pereiopods $1-5$ developed. telson with $8+8$ distal setae .............. zoea 11,4

2. No pterygostomic spines; rostrum without dorsal spines: somites without expansions and setation; abdominal somite 5 with short pair of lateral spines ........... Campylonotus vagans (zoea I)

- Pterygostomic spines present; somites with expansions: abdominal somite 5 with pair of long lateral spines $\ldots \ldots \ldots \ldots \ldots \ldots \ldots \ldots \ldots$

3. Rostrum elongated, with 15 small dorsal spines; first abdominal somite with dorsal margin anteriorly and posteriorly expanded; abdominal somites $2-5$ with dorsal margin posteriorly expanded. but not anteriorly, somites with setation ..........

$$
\text { . Campylonotus semistriatus (zoea!) }
$$

- Rostrum without dorsal spines; first abdominal somite without expanded margins; abdominal somites 2-5 with expanded margins, somites ornamented with denticles . . . . . . . . . . . .......... Campylonotus capensis (zoea l)

4. Rostrum with 9 dorsal spines; anteroventral margin of carpace with pterygostomic spine and denticles: subraorbital spines present: 2 dorsomedial protuberances and 1 dorsal spine at base of rosirum well developed, directed anteriorly; abdominal somites 2-5 with dorsal margin expanded pos teriorly, not anteriorly; abdominal somite 5 with long spine at both lateral sides; dorsal and ventral margins of somites ornamented with denticles: large, fine feathered setae on ventral and dorsal surface $\ldots \ldots \ldots \ldots$ Campylonotus semistriatus (zoea II

- Abdominal somites 1-5 without posteriorly expanded dorsal margins and without denticles; somite 5 with shorter lateral spine on each side; rostrum with 2 dorsal spines at base

........................... Campylonotus

\section{DisCussion}

Caridean larvae show a great variability in number of larval stages and development (Fincham, 1979a, b; Criales and Anger, 1986; Villamar and Brusca, 1988; Thatje and Bacardit. 2000a). Consequently, observations on larval development in culture are very difficult, which explains the scarce number of complete descriptions from this decapod group (Wehrtmann and Báez, 1997).

Descriptions of caridean larvae separated from plankton samples are one way to extend the limited knowledge of larval development, but this method hardly allows a complete description of the larval cycle. In our case, campylonotid larvae obtained from various investigations in Magellanic waters serve as an ideal basis for first larval descriptions and more detailed studies in the future. The partial geographical separation of campylonotid species in the southernmost region of America and the confirmation of the first zoeal stage of $C$. vagans with larvae hatched in the laboratory, allows unambiguous identification of the species of the larvae studied.

The zoea I larvae described in this work are different from that of C. rathbunae published by Pike and Williamson (1966; Table 1). Of all four species of the Campylonotidae, $C$. capensis shows the most developed zoea I, as shown by the well-developed pereiopods 1 and 2 and the presence of setae on pereiopods 1 to 4 , though the three last pairs are not segmented yet. Morphologically, the first zoea of C. rathbunae described by Pike and Williamson (1966) seems to be closely related to that of $C$. vagans, mainly due to the $a b$ sence of pterygostomic and rostral spines and the absence of expansions on the abdominal somites in both species (Table 1). On the other hand, abdominal expansions and the presence of pterygostomic spines relate first zoeae of $C$. capensis to that of $C$. semistriatus (Table 1). Zoeae II of the examined species (C. vagans, C. semistriatus) are quite advanced, resembling very much the features of adults (compare with Retamal, 1981).

Although adults of $C$. vagans are very common within the Magellan region and have a wide distribution pattern (Torti and Boschi, 1973: Gorny. 1999), larvae of this species were rare in plankton samples. Monthly

Table I. Morphological differences between zoeae I of the Campylonotidae.

\begin{tabular}{|c|c|c|c|c|}
\hline & C. rulihbunter & C. ctorensis & C. semisitintus & C. Mems \\
\hline Dorsal rostral spines & - & - & + & - \\
\hline Pterygostomic spines & - & + & + & - \\
\hline Dursal protuberances on carapice & - & + & + & + \\
\hline Expansious on first abdominal segment & - & - & + & - \\
\hline Setae on exopords of maxillipeds $[-3$ & $8 \cdot 16 \cdot 18$ & $14-22-24$ & $14-16-26$ & $9-14-17$ \\
\hline Setae on endopods of pereiopods $1-5$ &.++0.0 .0 &..,++++.0 &..+++.0 .0 &,,+++.0 .0 \\
\hline
\end{tabular}

- absernt: + present. 
plankton catches were carried out in the southwestern Atlantic Ocean from April 1978 to April 1979, but generally campylonotid larvae occurred only in samples from September to October 1978. These observations could assume an abbreviated and probably rapid development with a shortened planktonic larval phase of campylonotid larvae. First zoeae of $C$. vagans hatched in the laboratory showed a strong demersal behaviour, which may explain the absence of a more developed zoeal stage in plankton catches, as well as it supports the assumption of an abbreviated larval development. However, campylonotid larvae need at least a third zoeal stage to acquire a telson with elongated uropods typical for a late caridean larval stage. However, these assumptions must be checked in future laboratory culturing of campylonotid larvae.

Pike and Williamson (1966) compared zoeae of C. rathbunae with those of the families Pandalidae, Palaemonidae, and Oplophoridae. According to those authors, the long slender rostrum, the fringes of denticles on the carapace and abdominal somites, the shape of the mandible, and the presence of a long exopod on the third maxilliped are characters that zoeae of $C$. rathbunae share with some of the Pandalidae. These similarities occur also with respect to the larvae of $C$. semistriatus, $C$. vagans, and $C$. capensis.

Although the structure of the antennal flagellum of the zoeae I of Campylonotus is similar to that described for some Palaemonidae (see: Palaemon elegans, $P$. longirostris, $P$. serratus; Fincham, 1977, 1979b, 1983), the other characters relating zoeae of both families, such as supraorbital and pterygostomic spines, absence of external seta on the maxillule, shape of first antenna, and well-developed lateral spines on the fifth abdominal somite, are also present in some members of other families of Caridea, such as the Pandalidae (e.g., Pandalus jordani, see Rothlisberg, 1980: Austropandalus grayi, see Thatje and Bacardit, 2000b), and the Hippolytidae (e.g., Spirontocaris spinus, Spirontocaris lilljeborgii, see Pike and Williamson, 1961; Latreutes laminirostris, see Kim and Hong, 1999). Pike and Williamson (1966) pointed out that although larvae of $C$. rathbunae resemble zoeae of Pandalidae, the structure of the appendages is very similar to those of Oplophoridae, basically for the presence of four well-developed endites on the maxilla, exopods on all pereiopods, and absence of external setae on the maxillule (e.g., Acanthephyra purpurea, see Williamson, 1962; see also Kemp, 1907). Williamson (personal communication) remarks that these characters are more important from a phylogenetical point of view and that the presence of two coxal endites in the maxilla discards all close relations between the Campylonotidae and the Palaemonidae.

Relations between adult forms of species of this family are also subject to discussion. Borradaile (1907) and Balss (1957) grouped campylonotid species along with Oplophoridae, whereas Holthuis (1955) put them together with the Palaemonidae and Gnatophyllidae within the superfamily Palaemonoidea.

The presented larval morphology of the three additional campylonotid species supports considerably the proposed relations to the Oplophoridae as stated by the two former authors.

\section{ACKNOWLEDGEMENTS}

The authors' thanks are due to Drs. E. E. Boschi and W. E. Arntz for their great support of this work, and to Dr. I. Wehrtmann and two anonymous reviewers for their constructive comments on the manuscript. Special thanks of the second author are due to Dr. D. I. Williamson for his suggestions and discussions on the theme during the time of her thesis. The "Instituto Nacional de Investigación y Desarrollo Pesquero" (INIDEP) provided part of the plankton samples. Scientific work of the first author in South America was supported by the International Bureau of the German Ministry of Research (BMBF, project No. CHLCIA1A). This is Alfred Wegener Institute publication No. 1623.

\section{Literature Cited}

Albornoz, L., and 1. S. Wehrtmann. 1997. Descripción y clave de los primeros estadios larvales de camarones carideos (Decapoda: Hippolytidae, Alpheidae, Rhynchocinetidae) de aguas costeras de Chile.-Investigaciones Marinas, Valparaíso 25: $121-133$.

Balss, H. 1957. Bronn's Kleine Ordnung des Tierreichs, 5 Bd., 1. Abteilung, 7. Buch Decapoda, VIIl Systematik: I505-1672.

Borradaile, L. A. 1907. On the classitication of the decapod crustaceans.-Annales and Magazine of Natura! History 19: 457-486.

Boschi, E. E. 1981. Larvas de Crustacea Decapoda. Pp. 699-718 in D. Boltovskoy. ed. Atlas de zooplancton del Atlántico Sudoccidental y métodos de trabajo con el zooplancton marino. Instituto Nacional de Investigación y Desarrollo Pesquero. Mar del Plata.

Ciechomski. J. D.. M. D. Ehrilich, C. A. Lasta, and R. P. Sanchez. 1979. Campañas realizadas por el buque de investigación "Walther Herwig" en el Mar Argentino. desde mayo hasta noviembre 1978. Organización y reseñal de datos básicos obtenidos.-Contrib. Instituto 
Nacional de Investigación y Desarrollo Pesquero, Mar del Plata 374: 1-311.

Clark, P. F., D. K. Calazans, and G. W. Pohle. 1998. Accuracy and standardization of brachyuran larval descriptions.-Invertebrate Reproduction and Development 33: 127-144.

Cousseau, M. B., J. E. Hansen, and D. Gru. 1979. Campañas realizadas por el buque de investigación "Shinkai Maru" en el Mar Argentino, desde abril de 1978 hasta abril de 1979. Organización y reseña de datos obtenidos.-Instituto Nacional de Investigación y Desarrollo Pesquero, Mar del Plata 373: 1-625.

Criales, M. M., and K. Anger. 1986. Experimental studies on the larval development of the shrimps Crangon crangon and $C$, allmanni.-Helgoländer wissenschaftliche Meeresuntersuchungen 40: 241-265.

Fincham, A. A. 1977. Larval development of British prawns and shrimps (Crustacea: Decapoda: Natantia). 1. Laboratory methods and a review of Palaemon (Paleander) elegans Rathke 1837.-Bulletin of the British Museum (Natural History) Miscellanea Zoology Series 32: 1-28.

. 1979a. Larval development of British prawns and shrimps (Crustacea: Decapoda: Natantia). 2. Palaemonetes (Palaemonetes) varians (Leach, 1814) and morphological variation.-Bulletin of the British Museum (Natural History) Miscellanea Zoology Series 35: 164-182.

1979b. Larval development of British prawns and shrimps (Crustacea: Decapoda: Natantia). 3. Palae mon (Palaemon) longirostris H. Milne Edwards, 1837 and the effect of antibiotic on morphogenesis.-Bulletin of the British Museum (Natural History) Miscellanea Zoology Series 37: 17-46.

1983. Larval development of British prawns and shrimps (Crustacea: Decapoda: Natantia). 4. Palaemon (Palaemon) serratus (Pennant, 1777) and functional morphology of swimming.-mbulletin of the British Museum (Natural History) Miscellanea Zoology Series 44: 125-161.

Gorny, M. 1999. On the biogeography and ecology of the Southern Ocean decapod fauna.-Scientia Marina 63 (Suppl. 1): 367-382.

Gurney. R. 1942. Larvae of Decapod Crustacea. Ray Society. London. $306 \mathrm{pp}$.

Haynes. E. B. 1978. Description of larvae of a hippolytid shrimp, Lebbeus groenlandicus, reared in situ in Kachemay Bay, Alaska.-mishery Bulletin, U.S. 76: $457-465$.

- 1981. Early zoeal stages of Lebbeus polaris, Eualus suckleyi, E. fabricii, Spirontocaris arcuata, $S$. ochotensis, and Heptacarpus camtschaticus (Crustacea: Decapoda: Caridea: Hippolytidae) and morphological characterization of zoeae of Spirontocaris and related genera.-Fishery Bulletin, U.S. 79: 421-440.

- 1985. Morphological development, identifica. tion, and biology of larvae of Pandalidae, Hippolytidae, and Crangonidae (Crustacea: Decapoda) of the northern north Pacific Ocean.-Fishery Bulletin, U.S. 83: 253-288.

Holthuis, L. B. 1955. The Recent genera of caridean and stenopodidean shrimps (class Crustacea, order Decapoda, supersection Natantia) with keys for their determination. -Zoologische Verhandlungen, Leiden 26: 1-157.

Kemp. S. W. 1907. Biscayan plankton. Decapoda.Transactions of the Linnean Society of London, Zoology $2: 205-217$
Kim, J. N., and S. Y. Hong. 1999. Larval development of Latreutes laminirostris (Decapoda: Hippolytidae) reared in the laboratory.--Journal of Crustacean Biology 19: 762-781.

Lovrich, G. A. 1999. Seasonality of larvae of Brachyura and Anomura (Crustacea Decapoda) in the Beagle Channel, Argentina.-Scientia Marina 63 (Suppl. 1): 347-354.

Pike, R. B., and D. I. Williamson. 1961. The larvae of Spirontocaris and related genera (Decapoda, Hippolytidae).-Crustaceana 2: 187-207.

- and 1966 . The first zoeal stage of Campylonotus rathbunae Schmitt and its bearing on the systematical position of the Campylonotidae (Decapoda, Caridea).-Transactions of the Royal Society, New Zealand, Zoology 7: 209-213.

Retamal, M. A. 1981. Catálogo ilustrado de los crustáceos decápodos de Chile.-Gayana, Zoología 44: $1-110$.

Rothlisberg, P. C. 1980. A complete larval description of Pandalus jordani Rathbun (Decapoda, Pandalidae) and its relation to other species of the genus Pandalus.-Crustaceana 38: 19-48

Spivak, E. D. 1997. Los crustáceos decápodos del Atlántico sudoccidental $\left(25^{\circ}-55^{\circ} \mathrm{S}\right)$ : distribución y ciclos de vida.-Investigaciones Marinas, Valparaíso 25: 73-92.

Thatje, S., and R. Bacardit. 2000a. Morphological variability in larval stages of Nauticaris magellanica (A. Milne Edwards, 1891) (Decapoda: Caridea: Hippolytidae) from South American waters. - Bulletin of Matine Science 66: 375-398.

- and 2000b. Larval development of Austropandalus grayi (Cunningham, 1871) (Decapoda, Caridea, Pandalidae) from the southwestern Atlantic Ocean.-Crustaceana 73: 609-628.

, and E. Mutschke. 1999. Distribution of abundance, biomass, production and productivity of macrozoobenthos in the sub-Antarctic Magellan Province (South America).-Polar Biology 22: 31-37.

Torti, M. R., and E. E. Boschi. 1973. Nuevos aportes al conocimiento de los crustáceos decápodos Caridea del género Campylonotus Bate, 1888.-Physis (Buenos Aires) 32: 65-84.

Villamar, D. F., and G. J. Brusca. 1988. Variation in the larval development of Crangon nigricauda (Decapoda: Caridea), with notes on larval morphology and behaviour-Dournal of Crustacean Biology 8: 410-419.

Wehrtmann, I., and P. Báez. 1997. Larvas y estadios tempranos de desarrollo de crustáceos decápodos de Chile: descripciones publicadas.--Investigaciones Marinas. Valparaíso 25: 263-276.

Williamson, D. I. 1960. Larval stages of Pasiphaea sivado and some other Pasiphaeidae (Decapoda).Crustaceana 1: 331-341.

1962. Crustacea Decapoda: Larvae III. Caridea, Families Oplophoridae, Nematocarcinidae and Pasiphaeidae.-Fiches Identification Zooplancton 92: $1-5$.

. 1968. Names of larvae in the Decapoda and Euphausiacea.-Crustaceana 16:210 213 .

. 1982. Larval morphology and diversity. $\mathrm{Pp}$. 43-110 in D. E. Bliss, ed. The Biology of Crustacea 2. Academic Press, New York.

ReCEIVEd: 17 September 1999

ACCEPTED: 17 August 2000. 